ROVERSI PIO FEDERICO $(*)$ - BINAZZI FRANCESCO $(*)$ - MARIANELLI LEONARDO $(*)$

COSTI ELENA $(* *)$ - MAISTRELLO LARA $(* *)$ - SABBATINI PEVERIERI GIUSEPPINO $(*)$

\title{
SEARCHING FOR NATIVE EGG-PARASITOIDS OF THE INVASIVE ALIEN SPECIES HALYOMORPHA HALYS STÅL (HETEROPTERA PENTATOMIDAE) IN SOUTHERN EUROPE
}

\begin{abstract}
(*) Consiglio per la ricerca in agricoltura e l'analisi dell'economia agraria (CREA), Centro di ricerca per l'agrobiologia e la pedologia, Via Lanciola 12/A, 50125 - Florence, Italy; e-mail: piofederico.roversi@crea.gov.it (**) Dipartimento di Scienze della Vita, Università di Modena e Reggio Emilia, Via G. Amendola 2, 42122 - Reggio Emilia, Italy.
\end{abstract}

Roversi P.F., Binazzi F., Marianelli L., Costi E., Maistrello L., Sabbatini Peverieri G. - Searching for native egg-parasitoids of the invasive alien species Halyomorpha halys Stål (Heteroptera Pentatomidae) in Southern Europe.

Halyomorpha halys is an invasive species, originating from East Asia, which was accidentally introduced in some areas of North America and Europe, where severe damages to different vegetable crops and fruit plants were recorded. Several studies in different countries focused on the possibility to apply biological control by means of eggparasitoids. The main egg-parasitoids in the original area are unfortunately non-specific and thus the application of classical biological control is questionable. On the other hand, the possibility of using augmentative biological control by native egg-parasitoids able to exploit the new host is an interesting possibility in both Europe and the USA. In a preliminary assay, frozen egg masses of $H$. halys were exposed in the field in Central Italy. Results showed that some eggs were exploited by parasitoids belonging to the species Anastatus bifasciatus and Ooencyrtus telenomicida. Therefore, different native egg-parasitoids species widespread in Europe were tested in the laboratory in order to explore their ability to parasitize $H$. halys eggs. To this end, no-choice tests were carried out in climatic chambers $\left(26^{\circ} \mathrm{C}, 70 \% \mathrm{RH}, 16: 8 \mathrm{~L}: \mathrm{D}\right)$ in order to evaluate the parasitization potential of females collected in the wild. Conducted tests pointed out that $A$. bifasciatus and especially $O$. telenomicida may be potential candidates for the biological control of $H$. halys. In particular, O. telenomicida was able to parasitize the $35.56 \%$ of the exposed host eggs in the lab tests. New adults successfully emerged from the $22.92 \%$ of the eggs, and on the whole, this egg-parasitoid caused a significant hatching reduction of the H. halys eggs (more than 70\%). Conversely, Telenomus chloropus and Ooencyrtus pityocampae were less promising species as biocontrol agents of this agricultural pest. Preliminary trials in pear orchards consisting of field releases of laboratory-reared specimens of $O$. telenomicida, one of the potential candidates for biological control, showed that this parasitoid is actually able to discover egg masses of $H$. halys (sentinel frozen egg masses) and to successfully parasitize them.

KEY WoRDS: pest control, biological control, Brown Marmorated Stink Bug, natural enemy.

\section{INTRODUCTION}

Halyomorpha halys Stål (Heteroptera, Pentatomidae) is a polyphagous and herbivore insect species originating from East Asia, which became invasive in many regions of the World. The first records in the field, outside its original area, were reported in Pennsylvania USA, in 2001 (HoEBEKE and CARTER, 2003). In Europe, $H$. halys was officially recorded for the first time in Switzerland in 2007 (WERMELINGER et al., 2008) while, in Italy, it was observed in 2012 in Modena (Emilia Romagna Region, Northern Italy) (MAISTRELlo et al., 2014). Subsequently, further records were also reported in other regions of Northern Italy (Lombardy, Piedmont, Veneto and Friuli Venezia Giulia) and Central Italy (Tuscany) (BARISElli et al., 2016; MAISTRELlo et al. 2016; SFR Regione Toscana, 2016; SFR Regione FVG, 2015). Genetic analyses showed that Italian populations may have reached the mainland following two different routes, the first from Switzerland and the second from Asia and/or North America (CESARI et al., 2015). In all the new invaded regions $H$. halys spread more or less rapidly, becoming, worldwide, a serious pest due to its capacity to damage field and vegetable crops and tree fruit orchards (HAYE et al., 2015a; HoebeKe \& CARTER, 2003). Soybean, peaches, pears, apples, cherries are only some examples of strongly damaged plants (BERNON, 2004). H. halys feeds on the green parts of plants even if the most severe damages are generally recorded on fruits, which are often rendered unmarketable. Females lay their eggs during the growing season on the underside of plant leaves, in monolayer egg masses with approximately 28 eggs per batch (BERNON, 2004; Rice et al., 2014). Moreover, it is able to develop one, two or more generations per year, depending mainly on temperature (LEE et al. 2013). So far, control methods of this invasive species have been based on non-selective chemicals, which, however, led to contradictory results in terms of efficacy (LEE et al., 2013; HeRLiHY et al., 2016). Aggregation pheromones are also available even though they are suitable only for population monitoring, but not for mass trapping or sex disruption (LESKEY et al., 2012; HERLIHY et al., 2016). Therefore, more attention has been recently paid to biological control strategies and different studies have been performed in the USA, Europe and Asia (HAYE et al., 2015b; Herlihy et al., 2016; Rice et al., 2014; OGBURN et al., 2016). Investigations conducted in the field of classical biological control emphasized the potential use 
of egg-parasitoids native to the original area of the pest (TALAMAS et al., 2015, LARA et al., 2016). However, the most interesting candidates of the $H$. halys egg-parasitoid complex [i.e. Trissolcus japonicus Ashmead and Trissolcus cultratus Mayr (Hymenoptera, Platygastridae)] did not show any host specificity (HAYE et al., 2015b). The risk of using generalist species (with more or less host fidelity) in classical biological control is well known by experts and institutions (e.g. FAO, EPPO, IPPC), and many recommendations have been given for a careful use (Simberloff \& Stiling, 1996; Messing \& Wright, 2006; VAN LENTEREN et al., 2003). Therefore, more recently, the focus has been on exploring the possibility to use native eggparasitoids to control invasive species through augmentative approaches (Sivinski, 2013; COLLIER \& VAN STEENWYK, 2004; ChailleuX et al., 2012). Studies aimed at selecting potential candidates from among native egg-parasitoids, to control $H$. halys, have been performed in Europe and in USA (HAYE et al., 2015b; HerLiHy et al., 2016). Regrettably, much more remains to be done and further investigations in different countries are required in order to search for an effective biocontrol agent to be used in augmentative control programs. Despite these difficulties, biological control is still regarded as "the most environmentally safe and economically profitable pest management method" (VAN LENTEREN, 2012). Moreover, biocontrol agents of $H$. halys could be also considered as a "complex" of more species (HAYE et al., 2015b). In fact, as in a "joint venture", they might play a significant role in the control of $H$. halys, and represent a key element of IPM strategies.

In the present work, native egg-parasitoids collected in Central Italy were investigated in order to evaluate their ability to exploit eggs of $H$. halys. In particular, the aim was to found effective native natural enemy/ies of this invasive pest to be used in augmentative biological control programs.

\section{MATERIALS AND METHODS}

ORIGIN OF THE INSECTS AND REARING PROCEDURE

In June 2016, a $H$. halys laboratory colony was established by field collection of adults and juveniles on hedgerows (Laurus nobilis, Prunus laurocerasus) and fruit trees (Pyrus communis, Ficus carica, Prunus domestica, Prunus avium) in Tuscany (Central Italy). Adult specimens were laboratory reared in insect cages $(30 \times 30 \times 70 \mathrm{~cm})$ with screen mesh and provided with hand paper stripes as ovipositioning substrate; fresh beans of Phaseolus vulgaris and seeds of Arachis hypogaea were offered as food and replaced three times per week, while a water source was added through moistened cotton. Eggs and juveniles of all stages were reared in small transparent plastic boxes $(24 \times 18 \times 6 \mathrm{~cm})$ with a screen mesh for ventilation. Fresh beans of $P$. vulgaris were offered as food that was replaced three times per week. Once young individuals reached the adult stage, they were transferred from the plastic boxes into the insect cages. Egg masses of $H$. halys were daily removed, producing a set of fresh egg masses $(<24 \mathrm{~h}$ old $)$ to use in the tests. Insect rearing was performed in an environmentally controlled rearing room at $26^{\circ} \mathrm{C}$ and 16:8 L:D photoperiod.

In order to obtain suitable egg-parasitoid species to test in the present work, eggs of Dolycoris baccarum L. (Heteroptera, Pentatomidae) and Gonocerus juniperi (Herrich-Schaeffer) (Heteroptera, Coreidae) were collected during June-July 2016 on Juniperus communis and Corylus avellana in uncultivated areas of Tuscany (mixed flora in the herbaceous layer, with bushes and trees of Spartium junceum, J. communis, C. avellana, Acer campestris, Cupressus sempervirens) not yet known to be infested by $H$. halys. Field-collected eggs were reared individually in glass tubes ( $15 \mathrm{~cm}$ long, $2 \mathrm{~cm} \varnothing$ ) closed at both ends with screen mesh and located in climatic chambers at $26^{\circ} \mathrm{C}, 70 \% \mathrm{RH}$ and 16:8 L:D (standard rearing and test conditions adopted in the present work), until egg hatching or egg-parasitoids emergence. Emerged egg-parasitoids were identified, sexed and reared in glass tubes where they were fed with pure honey ad libitum. From field collected heteropteran eggs, the following egg-parasitoids emerged: Ooencyrtus telenomicida (Vassiliev) (Hymenoptera, Encyrtidae), Telenomus chloropus (Thomson) (Hymenoptera, Platygastridae) and Anastatus bifasciatus (Geoffroy) (Hymenoptera, Eupelimdae). From additional eggs of Thaumatopoea pityocampa (Den. et Shiff.) (Lepidoptera, Thaumetopoeidae) collected in mixed Pinus spp. stands in Tuscany, specimens of Ooencyrtus pityocampae (Mercet) (Hymenoptera, Encyrtidae) were obtained.

\section{EXPERIMENTAL PROCEDURES FOR LABORATORY TESTS}

In collected egg-parasitoid species that displayed sexual behavior (i.e. O. telenomicida, T. chloropus and A. bifasciatus), newly hatched females were housed individually in a glass tube and paired each with a male of the same species and origin for mating. Females and males were maintained at standard conditions in a climatic chamber for 5 days and fed with honey until the beginning of the tests. In eggparasitoid species which display a parthenogenetic reproduction behaviour (O. pityocampae), newly hatched females which emerged from the field-collected lepidopterans eggs, were housed individually for 5 days and reared in the same way, as described above, until the beginning of the test.

Parasitization ability of single field collected egg parasitoids, was tested in a no-choice experiment, offering each female a single batch of fresh $H$. halys eggs $(<24 \mathrm{~h}$ old $)$ for $24 \mathrm{~h}$ in climatic chambers at standard conditions; only masses with 26-30 eggs were used in the tests. After parasitization, each egg-batch was removed from the test tube, reared at standard conditions in a separate glass tube and daily checked until eggs hatched or egg-parasitoids emerged. In the tests the following parameters were recorded: $n$. of hatched eggs (n. of eggs from which a nymph of $H$. halys emerged), n. of parasitized eggs (n. of eggs with signs of parasitization as described below), n. of successfully parasitized eggs (n. of eggs from which at least one eggparasitoid successfully emerged), n. of eggs with no host hatching and no egg-parasitoid emergence, n. of emerged egg-parasitoids, their sex ratio $[Q /(q+\hat{O})]$ and their juvenile development time (in days). By careful inspection of $H$. halys eggs exposed to the egg-parasitoid females, some specific signs revealing the occurrence of parasitization were observed. In particular, in both Ooencyrtus species one or more egg stalks protruding outside the host chorion were visible, while in A. bifasciatus, a dark spot on the egg chorion where the female inserted the ovipositor was detected; moreover, parasitized host eggs generally turned to black few days after parasitization (MAPLE, 1947; VIGGIANI, 1994). All tests were replicated 10 times per each eggparasitoid species.

\section{FIELD EXPOSURE OF FROZEN $H$. HALYS EGGS} IN NON-INFESTED SITES

Freeze-killed sentinel eggs, were exposed in Tuscany in non-infested areas, with the purpose of investigating the ability of native egg-parasitoids to detect and parasitize 
them in the field. Fresh egg masses of H. halys (n. 20 masses of 26.05 eggs on overage) were collected from the rearing units in the laboratory, freeze-killed at $-80^{\circ} \mathrm{C}$ (Haier® ULT Freezer DW86L388) and then stored for 7-14 days. Several studies stressed that, generally, freezing host eggs at low and/or ultra-low temperatures does not significantly affect the egg-parasitoid capacity to complete their development, and frozen egg masses, including those of $H$. halys, are often used in several studies as sentinel eggs (BINAzZi et al. 2015a; HAYE et al., 2015b; SABBATINI PeVerieri et al., 2015; Herlihy et al., 2016). However, it is also known that the use of sentinel eggs, even if not frozen, can underestimate rates of parasitism and species complex (JONES et al., 2014).

In this work frozen eggs have been exposed for 3 days in the field in the same sites where egg masses of other heteropterans had been collected to obtain the egg parasitoids (described above). H. halys frozen eggs have been exposed once a month from May to August 2016, using each time 5 egg masses (see Results for details). Once removed from the field, the egg masses were reared at standard conditions in climatic chambers until eggparasitoids emerged. The emerged egg-parasitoids were then identified, counted and sexed.

\section{ABILITY OF A LAB-REARED EGG-PARASITOID} TO PARASITIZE EGGS IN AN $H$. HALYS INFESTED SITE

In an area of Modena Province in the Emilia-Romagna Region (Northern Italy), known to be infested by $H$. halys (MAistrello et al., 2016), 6 organic pear orchards were selected at the end of August 2016, in order to perform a preliminary tests in the field using the most promising eggparasitoid selected in the present work. The scope was to investigate the ability of the selected egg-parasitoid to detect and parasitize under field conditions, the eggs of $H$. halys. In a field study performed throughout the previous two years using fresh sentinel egg masses in the same area of tests, only A. bifasciatus had emerged (Costi et al., 2016; Maistrello, pers. comm.).

In order to carry out the trials, fresh egg masses of $H$. halys laid by females on paper stripes were collected from the rearing unit and treated in the same way we described above (n. 90 egg masses of 26.34 eggs on average). Before freezing at $-80^{\circ} \mathrm{C}$, each egg mass had been individually fastened by staples on a green cardboard $(1.5 \mathrm{~cm} \times 8 \mathrm{~cm})$.

On September 13, 2016, in 4 pear orchards of the 6 previously selected, egg masses were exposed directly on pear trees in a central area of the orchard, while in the other 2 orchards, egg masses were exposed on the hedgerows close to the pears (see Results) for details; hedgerows were set at a distance of approximately $3 \mathrm{~m}$ from the first row of pear trees in the orchard). In the experimental design of each of the first 4 sites, 4 pear trees were selected in a square, where each tree was located at one edge of the figure and a fifth tree was in the middle of it. On the whole, pear trees belonged to three different and consecutive plant rows of the orchard. In the other 2 sites, in mixed hedgerows, $H$. halys egg masses were set on 5 plants along the border, at a distance of $2 \mathrm{~m}$ between trees. In total, 30 plants were selected for the tests, 5 plants per each site.

In the field, cardboards bearing $H$. halys egg masses were fastened on the underside of plant leaves by wire paper clips. On each of the selected plants (in both the pear orchards and the hedgerows), 3 egg masses were fastened, one at each of the following heights from the soil: $1 \mathrm{~m}, 1.5 \mathrm{~m}$ and $2 \mathrm{~m}$. In every site, the selected egg-parasitoid were released from adequate dispensers soon after the egg masses had been fixed on the plants. The egg-parasitoids dispensers consisted of the same type of glass tubes used for rearing in the laboratory, and were fastened at $1.5 \mathrm{~m}$ in height from the soil on the trunk or main stem of each plant. Leaves bearing $H$. halys egg masses were approximately at $50 \mathrm{~cm}$ from the release dispenser. Field exposure of $H$. halys was designed so has to remove them after 2 days from the egg-parasitoid release (HeRLiHY et al., 2016). Then, removed eggs were reared under standard conditions in a climatic chamber until egg-parasitoids emergence.

The data obtained in the present work (see Results) suggested that $O$. telenomicida might be a valid candidate for the field control of $H$. halys. Hence this species was selected in order to plan the further field releases trials. In fact, $O$. telenomicida is a polyphagous species that can be easily reared on many different hosts in the laboratory, among these, Graphosoma lineatum L. (Heteroptera Pentatomidae) (Roversi, pers. comm.). Therefore, a colony of $O$. telenomicida was established in the laboratory and reared in a climatic chamber at standard conditions using $G$. lineatum eggs; host egg masses for the egg-parasitoid were obtained from a permanent laboratory colony previously established for different scientific purposes (BINAZZI et al., 2015b). Specimens of $O$. telenomicida used in the fieldrelease experiment were 5-10 days old and they had been fed with honey ad libitum until the release. Egg-parasitoids were released at a rate of 30 females and 30 males per plant, for a total of 1.800 specimens divided into 30 release units, one dispenser per selected plant.

\section{STATISTICAL ANALYSIS}

Data were tested for normality with the Shapiro-Wilk test (ZAR, 2010). Transformations were then applied but failed to normalize the data. Data were then analysed by KruskalWallis $H$ test and pairwise comparisons carried out by Mann-Whitney $U$ test (with Bonferroni correction) (ZAR, 2010). Statistical procedures were performed by the statistical software SPSS 20.0.0.

\section{RESULTS}

Performance OF THE EGG-PARASITOIDS

IN THE LABORATORY TESTS

The ability to parasitize $H$. halys shown by the different egg-parasitoids in laboratory no-choice tests was highly variable and only in few cases, parasitization was successful, with the emergence of new adults.

$H$. halys egg masses exposed to egg-parasitoids and those serving as control (not exposed to any egg-parasitoid) had an average of $27.38( \pm 0.21 \mathrm{SE})$ eggs/batch, and differences in the number of eggs per batch among the different groups, were not statistically significant $(H=6.427 ; \mathrm{df}=4 ; P=$ $0.166)$.

In the tests carried out with females of $O$. telenomicida, $35.56 \%( \pm 5.86 \mathrm{SE})$ of the exposed $H$. halys eggs were parasitized and the $22.92 \%( \pm 4.35 \mathrm{SE})$ of the total eggs exposed successfully produced egg-parasitoid offspring after the exposure (Table 1$)$. The $37.33 \%( \pm 8.69 \mathrm{SE})$ of the exposed eggs did not hatch, nor they produced any eggparasitoid, whereas only the $27.11 \%( \pm 8.63 \mathrm{SE})$ successfully hatched with the emergence of $H$. halys nymphs. Among the replicates, the maximum parasitization rate was $55.56 \%$, while the maximum rate of eggs from which no $H$. halys nymphs emerged (unviable eggs and /or killed by the egg-parasitoid) was $100 \%$. On the whole, from the 272 eggs of $H$. halys offered to the 10 females of $O$. 
Table 1 - Parasitization of Anastatus bifasciatus, Ooencyrtus telenomicida, Ooencyrtus pityocampae and Telenomus chloropus on eggs of Halyomorpha halys under laboratory conditions $\left(26^{\circ} \mathrm{C}, 70 \% \mathrm{RH}, 16: 8 \mathrm{~L}: \mathrm{D}\right)$.

\begin{tabular}{|c|c|c|c|c|c|c|c|c|c|c|}
\hline $\begin{array}{l}\text { Egg-parasitoid } \\
\text { species }\end{array}$ & $\begin{array}{l}\text { n. of } \\
\text { eggs/ } \\
\text { batch }^{1}\end{array}$ & $\begin{array}{c}\% \text { of } \\
\text { hatched } \\
\text { eggs }^{\mathrm{a}}\end{array}$ & $\begin{array}{c}\% \text { of } \\
\text { parasitized } \\
\text { eggs }{ }^{\text {a }}\end{array}$ & $\begin{array}{l}\% \text { of host } \\
\text { eggs with } \\
\text { parasitoid } \\
\text { emergence }^{\mathrm{a}}\end{array}$ & $\begin{array}{l}\% \text { of eggs } \\
\text { with no host } \\
\text { hatching and } \\
\text { no parasitoid } \\
\text { emergence }^{\mathrm{a}}\end{array}$ & $\begin{array}{c}\text { n. of emerged } \\
\text { parasitoids/ } \\
\text { total n. of } \\
\text { exposed } H . \\
\text { halys eggs }\end{array}$ & $\begin{array}{l}\text { Sex ratio \% } \\
{[q /(++\hat{O})]}\end{array}$ & $\begin{array}{l}\text { n. of } \\
\text { females } \\
\text { producing } \\
\text { offspring/ } \\
\text { tot. females } \\
\text { tested }\end{array}$ & $\begin{array}{c}\text { Female } \\
\text { develop- } \\
\text { ment time } \\
\text { (days) }\end{array}$ & $\begin{array}{l}\text { Male } \\
\text { develop- } \\
\text { ment time } \\
\text { (days) }\end{array}$ \\
\hline $\begin{array}{l}\text { Anastatus } \\
\text { bifasciatus }\end{array}$ & $\begin{array}{c}27.80 \\
( \pm 0.25) \\
a\end{array}$ & $\begin{array}{c}65.38 \\
( \pm 9.62) \\
a\end{array}$ & $\begin{array}{c}20.36 \\
( \pm 8.59) \\
\mathrm{ab}\end{array}$ & $\begin{array}{c}15.00 \\
( \pm 6.79) \\
\mathrm{ab}\end{array}$ & $\begin{array}{c}14.26 \\
( \pm 5.08) \\
\mathrm{ab}\end{array}$ & $42 / 278$ & $\begin{array}{c}32.50 \\
( \pm 13.51)\end{array}$ & $4 / 10$ & $\begin{array}{c}21.43 \\
( \pm 0.19)\end{array}$ & $\begin{array}{c}20.67 \\
( \pm 0.18)\end{array}$ \\
\hline $\begin{array}{l}\text { Ooencyrtus } \\
\text { telenomicida }\end{array}$ & $\begin{array}{c}27.20 \\
( \pm 0.42) \\
a \\
\end{array}$ & $\begin{array}{c}27.11 \\
( \pm 8.63) \\
a\end{array}$ & $\begin{array}{c}35.56 \\
( \pm 5.86) \\
a \\
\end{array}$ & $\begin{array}{c}22.92 \\
( \pm 4.35) \\
a\end{array}$ & $\begin{array}{c}37.33 \\
( \pm 8.69) \\
a\end{array}$ & $111 / 272$ & $\begin{array}{c}72.89 \\
( \pm 9.02)\end{array}$ & $9 / 10$ & $\begin{array}{c}15.02 \\
( \pm 0.14)\end{array}$ & $\begin{array}{c}14.58 \\
( \pm 0.13)\end{array}$ \\
\hline $\begin{array}{l}\text { Ooencyrtus } \\
\text { pityocampae }\end{array}$ & $\begin{array}{c}27.70 \\
( \pm 0.42) \\
a\end{array}$ & $\begin{array}{c}44.88 \\
( \pm 9.20) \\
\mathrm{a}\end{array}$ & $\begin{array}{c}20.88 \\
( \pm 7.02) \\
\mathrm{ab}\end{array}$ & $\begin{array}{c}0.00 \\
\mathrm{~b}\end{array}$ & $\begin{array}{c}34.25 \\
( \pm 7.66) \\
\mathrm{a}\end{array}$ & $0 / 277$ & - & $0 / 10$ & - & - \\
\hline $\begin{array}{l}\text { Telenomus } \\
\text { chloropus }\end{array}$ & $\begin{array}{c}26.30 \\
( \pm 0.80) \\
a\end{array}$ & $\begin{array}{c}59.02 \\
( \pm 10.72) \\
\mathrm{ab}\end{array}$ & $\begin{array}{c}5.91 \\
( \pm 5.53) \\
b\end{array}$ & $\begin{array}{c}2.58 \\
( \pm 2.21) \\
b\end{array}$ & $\begin{array}{c}35.07 \\
( \pm 8.48) \\
a\end{array}$ & $7 / 263$ & 100 & $2 / 10$ & $\begin{array}{c}15.25 \\
( \pm 0.11)\end{array}$ & - \\
\hline $\begin{array}{l}\text { Control } H . \\
\text { halys eggs } \\
\text { without egg- } \\
\text { parasitoids }\end{array}$ & $\begin{array}{c}27.90 \\
( \pm 0.10) \\
a\end{array}$ & $\begin{array}{c}93.56 \\
( \pm 1.75) \\
b\end{array}$ & - & - & $\begin{array}{c}6.45 \\
( \pm 1.75) \\
b\end{array}$ & - & - & - & - & - \\
\hline
\end{tabular}

${ }^{1}$ Within columns, percentages $( \pm \mathrm{SE})$ followed by different letters are significantly different $(P<0.05)$.

telenomicida, 111 adults successfully emerged from the parasitized eggs, with a mean of $11.10( \pm 2.25 \mathrm{SE})$ adults per egg batch. Remarkably, all the tested females with only one exception accepted $H$. halys eggs as host. Offspring of $O$. telenomicida had a strong female biased sex ratio, $72.89 \%$ $( \pm 9.02 \mathrm{SE})$ and development time was of $15.02( \pm 0.14 \mathrm{SE})$ days for females and 14.58 ( $\pm 0.13 \mathrm{SE}$ ) days for males.

In tests conducted exposing $H$. halys eggs to $A$. bifasciatus females, the $20.36 \%$ ( \pm 8.59 SE) of the eggs were parasitized and the $15.00 \%$ ( $\pm 6.79 \mathrm{SE})$ successfully produced offspring. The percentage of $H$. halys eggs that successfully hatched was relatively high, $65.38 \%$ ( $\pm 9.62 \mathrm{SE})$, while the eggs with no host hatching and no egg-parasitoid emergence were the $14.26 \%( \pm 5.08 \mathrm{SE})$. In single cases, parasitization ability reached the $64.29 \%$ of the offered eggs and considering the total number of eggs that did not produce any $H$. halys nymph, the host mortality reached the $78.57 \%$ of the egg mass. On the whole, the $278 \mathrm{H}$. halys eggs exposed to the 10 females during the test, produced 42 egg-parasitoid adults, with a strong male-biased sex ratio, $32.50 \%( \pm 13.51 \mathrm{SE})$. Only 4 females accepted the egg masses, producing offspring from $H$. halys eggs. Juvenile development time was shorter in males, 20.67 ( $\pm 0.18 \mathrm{SE})$ days, than in females, $21.43( \pm 0.19 \mathrm{SE})$ days.

In the tests conducted with $T$. chloropus, a mean of $59.02 \%( \pm 10.72 \mathrm{SE})$ of the offered eggs hatched, while the $35.07 \%( \pm 8.48 \mathrm{SE})$ of them failed to hatch and did not produce any egg-parasitoid. Only the $5.91 \%( \pm 5.53 \mathrm{SE})$ of the exposed $H$. halys eggs were parasitized by females and successful emergence of new egg-parasitoids occurred from the $2.58 \%( \pm 2.21 \mathrm{SE})$ of eggs. Moreover, only two of the tested parental females accepted $H$. halys eggs for oviposition. In some cases, the presence of a T. chlorpous female in the test tube led to $100 \%$ mortality of $H$. halys eggs. However, only very few individuals and only females emerged from $H$. halys eggs; the adult stage was reached in $15.25( \pm 0.11 \mathrm{SE})$ days.

In the tests with $O$. pityocampae, the $44.88 \%( \pm 9.20 \mathrm{SE})$ of the H. halys exposed eggs hatched. Although the $20.88 \%$
$( \pm 7.02 \mathrm{SE})$ of them was parasitized, no egg-parasitoid offspring emerged. $H$. halys eggs that did not hatch were the $34.25 \%( \pm 7.66 \mathrm{SE})$.

Unexposed control eggs of $H$. halys had a mean hatching rate of $93.56 \%( \pm 1.75 \mathrm{SE})$ and significant differences were observed among the egg hatching rates of the different groups $(H=22.674 ; \mathrm{df}=4 ; \mathrm{n}=50 ; \mathrm{P}<0.0001)$ : when eggparasitoids were present (with the exception of $T$. chloropus), $H$. halys eggs hatched at lower rate than the control one (see Table 1).

Percentages of parasitized $H$. halys eggs were significantly different among the tested egg-parasitoid species $(H=7.905 ; \mathrm{df}=3 ; \mathrm{n}=40 ; \mathrm{P}=0.043): O$. telenomicida parasitized more eggs than T. chloropus. As regards the successfully parasitized eggs, differences were also significant $(H=17.60 ; \mathrm{df}=3 ; \mathrm{n}=40 ; P=0.0001)$. In particular, the proportion of eggs from which at least one egg-parasitoid emerged, was higher in $O$. telenomicida than in all the other species except for A. bifasciatus. Moreover, the percentage of $H$. halys eggs with no host hatching, and no egg-parasitoid emergence, was also significantly different among the tested species $(H=16.771$; df $=4$ : $\mathrm{n}=50 ; P=0.001)$. In fact, in this trial, both Ooencyrtus species and $T$. chloropus caused a host egg mortality higher than that recorded in the untreated control.

FIELD EXPOSURE OF FROZEN $H$. HALYS EGGS IN A NON-INFESTED AREA

As regards frozen eggs exposed in the field, data recorded on parasitization revealed that 9 of the exposed $H$. halys egg masses (n. 25 in total) were effectively detected by native egg-parasitoids, and that 59 eggs were successfully parasitized (Table 2). The 72 emerged egg-parasitoids belonged to the species $A$. bifasciatus and O. telenomicida, with the second species being clearly more numerous than the first one. Remarkably, in the light of the available data, A. bifasciatus seems to be more frequent in the first half of the growing season, while $O$. telenomicida appears to be predominant in the second half. 
Table 2 - Egg-parasitoids emerged from Halyomorpha halys frozen eggs exposed in the field for 3 days in 2016 in a non-infested site (uncultivated area in Central Italy, see text for details on site description).

\begin{tabular}{|c|c|c|c|c|c|}
\hline $\begin{array}{c}\text { Date of } H \text {. halys } \\
\text { eggs exposure }\end{array}$ & $\begin{array}{c}\text { Mean n. of } H \text {. halys } \\
\text { exposed eggs/egg } \\
\text { masses }\end{array}$ & $\begin{array}{l}\text { n. of egg masses } \\
\text { parasitized/total n. } \\
\text { egg masses exposed }\end{array}$ & $\begin{array}{l}\text { Mean } \% \text { of } \\
\text { parasitized eggs on } \\
\text { the total number of } \\
\text { eggs available in } \\
\text { detected egg masses }\end{array}$ & $\begin{array}{l}\text { Total n. of } \\
\text { emerged } \\
\text { parasitoids }\end{array}$ & Emerged parasitoid species \\
\hline $15^{\text {th }}$ May & 26.6 & $1 / 5$ & 10.71 & $3\left(1+9,2{ }^{\lambda}\right)$ & Anastatus bifasciatus \\
\hline $15^{\text {th }}$ June & 27.0 & $2 / 5$ & 9.4 & $4\left(1+9,3 \delta^{\Uparrow}\right)$ & Anastatus bifasciatus \\
\hline $19^{\text {th }}$ July & 25.6 & $2 / 5$ & 14.3 & $14(11+3,3 \overbrace{}^{\lambda})$ & Ooencyrtus telenomicida \\
\hline $10^{\text {th }}$ August & 25.0 & $3 / 5$ & 44.5 & $51\left(42+, 9 \bigcirc^{\Uparrow}\right)$ & Ooencyrtus telenomicida \\
\hline
\end{tabular}

ABILITY OF LABORATORY REARED EGG-PARASITOIDS TO PARASITIZE FROZEN $H$. HALYS EGGS IN AN INFESTED SITE

Despite the short time of exposure, O. telenomicida was able to detect the eggs of $H$. halys in the environment (on both pears and hedgerows) and to parasitize them (Table 3 ). Parasitized egg masses were recorded in 4 of the 6 study sites, thought only from 3 sites progeny was obtained. Number of detected egg masses and number of parasitized eggs were low, even if in single discovered egg masses, parasitized eggs reached the $25 \%$ of the total available eggs. From parasitized $H$. halys eggs, 15 adults (14 females and 1 male) successfully emerged.

\section{DISCUSSION}

In the present work, the egg-parasitoids obtained from field collections of native pentatomid and lepidopteran eggs were tested against $H$. halys. They all belonged to well-known generalist species: A. bifasciatus, $O$. telenomicida, O. pityocampae and T. chloropus (HuANG \& Noyes, 1994; Battisti et al., 1988; Viggiani, 1994; TRJAPITZIN, 1988). Moreover, all these field-collected species could be reared in the laboratory in a sufficient number to perform the tests.

HAYE et al. (2015b) assumed that generalist eggparasitoids of pentatomids would be the most likely candidates to successfully develop on $H$. halys, considering that they evolved effective strategies to overcome defense responses of a wide range of hosts (VINSON, 1990). In several cases, particularly in a medium/long-term perspective, native egg-parasitoids were reported to adapt to alien species exploiting them as new hosts. A recent example in Europe is the case of Dryocosmus kuriphilus Yasumatsu (Hymenoptera, Cynipidae), the chestnut gall wasp: after a decade from its accidental introduction, several cases were reported of parasitoids shifting from oak gall wasps to the chestnut gall wasp (QUACCHIA et al., 2013; MATOŠEvić \& MELIKA, 2013). That being said, it is often difficult to predict how much time is required to obtain an effective and economically sound natural control of invasive species by native organisms. To date, as regards $H$. halys, even if its introduction is suspected to have occurred in Europe before 2004, there is little evidence of field parasitization by native parasitoids. HAYE et al. (2015b) observed parasitization of field-exposed frozen eggs by $A$. bifasciatus and $T$. cultratus. In addition, field parasitization of fresh egg masses by A. bifasciatus was also reported in Northern Italy (Costi et al., 2016). Likewise, results consistent with previous studies were also found in this work. Conversely, in the USA, where $H$. halys was introduced in the early 90 's, several different species of eggparasitoids, including Ooencyrtus species, have adapted to the new host under field conditions (ABRAM et al., 2014; JONES et al., 2014; HeRlihy et al., 2016; CORNELIUS et al., 2016). However, so far, parasitization rates observed in the field have been extremely low for an effective control of the pest.

In Europe, HAYE et al. (2015b) tested in the laboratory different species of native egg-parasitoids (belonging to the genera Trissolcus, Telenomus, Anastatus), with the aim to select a candidate for augmentative biological control. These studies highlighted that $A$. bifasciatus is the most promising one and research on it is currently in progress. Nevertheless, the possibility that in other regions/habitats the parasitoid complex and the parasitization level of $H$. halys may be different from those so far observed cannot be excluded. In the present work, the focus was on O. telenomicida, a species that together with $A$. bifasciatus might play a key role as potential biocontrol agent of $H$. halys. Moreover, in

Table 3 - Parasitization of frozen eggs of Halyomorpha halys in a 2-day field trial in an infested site (pear orchards in Central Italy, $13^{\text {th }}-15^{\text {th }}$ September 2016) with the release of Ooencyrtus telenomicida laboratory reared specimens (see text for details).

\begin{tabular}{|c|c|c|c|c|c|}
\hline Site & Plants & $\begin{array}{l}\text { Mean n. of } \\
\text { H. halys exposed } \\
\text { eggs/egg masses }\end{array}$ & $\begin{array}{l}\text { N. of parasitized egg } \\
\text { masses/total n. of } \\
\text { exposed egg masses }\end{array}$ & $\begin{array}{l}\text { Mean } \% \text { of parasitized } \\
\text { eggs on the total number } \\
\text { of eggs available } \\
\text { (in detected egg masses) }\end{array}$ & $\begin{array}{l}\text { Total n. of } \\
\text { emerged } \\
\text { parasitoids }\end{array}$ \\
\hline SPA (orchard) & Pyrus communis & 26.27 & $1 / 15$ & 25.00 & $1(1+)$ \\
\hline RI (orchard) & Pyrus communis & 26.67 & $0 / 15$ & - & - \\
\hline $\mathrm{CO}$ (orchard) & Pyrus communis & 27.53 & $2 / 15$ & 13.99 & $10(10+9)$ \\
\hline COS (hedgerow) & $\begin{array}{l}\text { Populus alba, Carpinus } \\
\text { betulus, Cornus mas }\end{array}$ & 26.27 & $1 / 15$ & 25.00 & $4\left(3 ㅇ, 1{ }^{\lambda}\right)$ \\
\hline VA (orchard) & Pyrus communis & 25.27 & $1 / 15$ & 4.00 & 0 \\
\hline VAS (hedgerow) & Acer campestris & 25.07 & $0 / 15$ & - & - \\
\hline
\end{tabular}


accordance with HAYE et al. (2015b), the possibility to select a strain of the potential biocontrol agents specifically adapted to $H$. halys, may be an interesting perspective in augmentative releases of mass-produced specimens. In this context, $O$. telenomicida might be a valid candidate. Since it is widespread from Europe to China, and it is well adapted to biogeographical regions with a Mediterranean climate (SAMrA et al., 2015). On the other hand, the potential use of both $A$. bifasciatus and $O$. telenomicida in a simultaneous release is more questionable, since a partial overlapping of parasitization (i.e. hyperpasitism) might occur. In fact, $O$. telenomicida is a well-known hyperparasitoid and in $A$. bifasciatus the same behavior has been reported too (Viggiani, 1994; Catalán \& Verdú, 2005; Cusumano et al., 2011).

Conversely, T. chloropus was of minor interest since its parasitization ability resulted to be much lower than that observed in A. bifasciatus and O. telenomicida. Moreover, in contrast with the observations conducted in the present work, HAYE et al. (2015b) observed no offspring production in $T$. chloropus tested in laboratory on fresh host eggs. A reasonable explanation might be that different local populations of the same egg-parasitoid species could have a slightly different ability to exploit this pest. This is also the case of T. cultratus, which in China appears to be one of the most important control agents of $H$. halys beside $T$. japonicus, while in Europe it shows extremely low levels of parasitization, under both laboratory and field conditions (HAYE et al., 2015b).

On the whole, the most important finding was that $A$. bifasciatus and $O$. telenomicida showed a good capacity to successfully emerge from parasitized eggs of $H$. halys, i.e. parasitized host eggs producing viable offspring. In $O$. telenomicida, the development of juveniles took approximately 15 days in females and males. This result is consistent with data presented by CATALÁN \& VERDÚ (2005) and STEFANESCU et al. (2003), where this egg-parasitoid developed respectively on Nezara viridula L. (Heteroptera, Pentatomidae) and Iphiclides podalirius feisthamelii (Duponchel) (Lepidoptera: Papilionidae); data on sex ratio are also quite similar to those reported by the cited Authors. Though further research is necessary, data collected in the present work lead to speculate that the new host of $O$. telenomicida should not considerably affect its reproductive ability. O. telenomicida showed for each tested individual, a relatively high parasitization ability and in some cases the presence of adult females in the test tubes was associated with a $100 \%$ mortality of $H$. halys eggs. It is also worth mentioning that beside the parasitization ability, this eggparasitoid is also known for its host-feeding behavior, which can occur in the dead host (CUSUMANO et al., 2012). As it was observed by HAYE et al. (2015b), A. bifasciatus is also capable to exploit the new host, even if a fairly higher parasitization ability was reported compared with that recorded here.

Conversely, egg-parasitoids tested here and in HAYE et al. (2015b), even when they parasitized the host masses, generally failed to develop on fresh host eggs, while only in few cases successfully emerged from frozen host eggs. ABRAM et al. (2016) argued that in inundative biological control, the capacity to target and kill a maximum number of host eggs is more relevant than the ability to successfully emerge from them. In fact, parasitoids can contribute to the egg mortality of a pest in several ways such as probing eggs with the ovipositor, feeding on them or disrupting the embryogenesis. All these factors, individually or combined, may eventually lead to egg abortion (JERVIS \& KIDD, 1986;
ABRAM et al., 2016). This aspect should be particularly considered in the new host association, where due to a lack of co-evolutionary history, native egg-parasitoids may try to parasitize eggs with different results, such as the killing of the eggs, even without a successful emergence of new adults. This could be also the case of unhatched eggs of $H$. halys reported by ABRAM et al. (2014) and HAYE et al. (2015b). Similar findings were observed in the present study in the $O$. pityocampae test, where no offspring were produced but more than half of the exposed $H$. halys eggs failed to hatch in presence of the egg-parasitoid, and females parasitized effectively $1 / 5$ of the offered eggs.

However, all results in the present work were obtained in laboratory using no-choice tests, in which specimens were constrained within the test units. This is a severe limitation and transferring knowledge from the laboratory directly to the field may be complex while potential success difficult to predict. Therefore, further accurate studies in semi-field and field conditions are required to define the effective ability of the egg-parasitoid to detect target host eggs in the environment. Moreover, even if parasitization occurs at high levels, habitat fidelity of the control agent cannot be ignored and should be further investigated. HerLiHy et al., (2016) focused on habitat fidelity of different eggparasitoids: certain species were indeed more attracted to herbaceous vegetation, while others searched preferentially for habitats characterized by woody flora. Nonetheless, if, and what kind of environments are attractive to $O$. telenomicida or A. bifasciatus, is still a matter of further investigations. In fact, in the laboratory, single females of $O$. telenomicida and $A$. bifasciatus were able to parasitize relatively high percentages of eggs in an egg-mass, but the actual exploitation capacity of a batch in the field remains questionable.

In the present work, $O$. telenomicida was preferred to $A$. bifasciatus as potential biocontrol agent of $H$. halys and hence used in the field tests, on the basis of the following criteria: i) in laboratory, this species can be easily reared on different hosts (also on small-size ones, at least compared with those commonly exploited by $A$. bifasciatus); ii) parasitoid productivity for each single host egg of $H$. halys/G. lineatum (or other suitable hosts) is higher. In fact from an egg of $H$. halys/G. lineatum, 2-3 O. telenomicida specimens may emerge due to their the reduced body size compared to that of $A$. bifasciatus, (in bigger host eggs up to 6 specimens) (Stefanescu et al., 2003); iii) the development time is faster ( 15 days vs. the 3 weeks required by $A$. bifasciatus); iv) the will to diversify the research topics, optimizing general resources: in fact $A$. bifasciatus is already under investigation in an international project funded by the European Union (HAYE et al., 2015b).

Data obtained in the field trial (in pear orchards) designed to control $H$. halys by releasing laboratory reared $O$. telenomicida (on G. lineatum as host) showed that, despite the short period of host-egg exposure, this egg-parasitoid was able to detect and parasitize the target host, not only on pears, but also on hedgerows of mixed plant species. Some females of $O$. telenomicida were able to recognize eggs of $H$. halys, even though, in general, the parasitization parameters evidenced so far a low ability to detect eggs and parasitize them. This might be due to different factors: i) the reduced time of host exposure (higher parasitization levels could be expected after a longer exposure); ii) the non adequate timing of the trial, probably too late to meet the optimal conditions of the egg-parasitoid (data obtained in the present work showed that a high activity of $O$. telenomicida can be 
expected in the middle of August, while field tests were carried out in the middle of September); iii) the non optimal condition of sentinel eggs (even if frozen host eggs appeared suitable in tests conducted here and in other studies); vi) an excessively low egg-parasitoid/host ratio. Regarding the last, it is known that the release rate in an augmentative biological control program is a key factor in the success of a control strategy (CROWDER, 2007; COLlIER \& VAN STEENWYK, 2004). Nonetheless, the results obtained in this preliminary field trial with $O$. telenomicida are interesting and research is in progress in order to establish key parameters, such as those proposed by BIN and VINSON (1991): discovery efficiency, exploitation efficiency and parasitoid impact. Moreover, there are also some grounds for optimism, since studies of ABRAM et al. (2014), HERLIHY et al. (2014), Jones et al., 2014, HAYE et al. (2015b), OGBuRN et al. (2016), showed that fresh and frozen fieldexposed sentinel eggs of $H$. halys were effectively detected by several native egg-parasitoids in both the USA and Europe. The cited studies focused on several egg-parasitoid species included in the genera Anastatus, Trissolcus, Telenomus and Ooencyrtus, whose importance is variable at local scale. Nevertheless, so far, natural parasitization levels in the field have been generally very low and the control by other natural agents, such as predators, even if reported in many circumstances, is not sufficient to actually limit this pest (OGBURN et al., 2016).

\section{ACKNOWLEDGMENTS}

We wish to thank Andrea Rocchini, Giuseppe Vicario, Tiziano Fabbricatore and Riccardo Frosinini for the help in laboratory rearing of $H$. halys. We are also grateful to the Plant Protection Services of Tuscany and Emilia-Romagna Regions. Present work was supported by the project ASPROPI funded by MIPAAF (Italian Ministry of Agricultural Food and Forestry Policies) DM n. 28635, 2015/12/28.

\section{REFERENCES}

Abram P.K., Brodeur J., Burte V., Boivin G., 2016 Parasitoid-induced host egg abortion: an underappreciated component of biological control services provided by egg parasitoids. - Biological Control, 98: 5260.

Abram P.K., Gariépy T.D., BoIVIn G., Brodeur J., 2014 An invasive stink bug as an evolutionary trap for an indigenous egg parasitoid. - Biological Invasions, 16: 1387-1395.

Bariselli M., Bugiani R., Maistrello L., 2016 Distribution and damage caused by Halyomorpha halys in Italy. - Bulletin OEPP/EPPO Bulletin, 46(2): 332-334.

Battisti A., Colazza S., Roversi P.F., Tiberi R., 1988 Alternative hosts of Ooencyrtus pityocampae Mercet (Hymenoptera: Encyrtidae) in Italy. - Redia, 71: 321-328.

BERNON G., 2004 - Biology of Halyomorpha halys. The brown marmorated stink bug. - Final Report, United States Department of Agriculture, Animal and Plant Health Inspection Service, Center for Plant Health Science Technology, T3P01.

BIN F., Vinson S.B., 1991 - Efficiency assessment in egg parasitoids (Hymenoptera): proposal for a unified terminology. - In: WAJNBerG E., Vinson S.B. (eds.), Trichogramma and other egg parasitoids. San Antonio
(TX, USA), September 23-27, 1990. Les colloques de l'INRA 56, INRA editions, Paris, pp. 175-179.

Binazzi F., Sabbatini Peverieri G., Benassai D., Roversi P.F., 2015a - The effects of short-term cold storage on the survival of the endoparasitoid Ooencyrtus pityocampae Mercet (Hymenoptera Encyrtidae). - Redia, 98: 31-36.

Binazzi F., SAbbatini Peverieri G., Simoni S., Frosinini R., FabBricatore T., Roversi P.F., 2015b - An effective method for Graphosoma lineatum (L.) long-term rearing. - Redia, 98: 155-160.

Catalán J., Verdú M.J., 2005 - Evaluacion de dos parasitoides de huevos de Nezara viridula. - Boletín de Sanidad Vegetal Plagas, 3: 187-197.

Cesari M., Maistrello L., Ganzerli F., Dioli P., REBECCHI L., GUIDETTI R., 2015 - A pest alien invasion in progress: potential pathways of origin of the brown marmorated stink bug Halyomorpha halys populations in Italy. - Journal of Pest Science, 88: 1-7.

Chailleux A., Desneux N., Seguret J., Do Thi Khanh H., Maignet P., TABone E., 2012 - Assessing European Egg Parasitoids as a Mean of Controlling the Invasive South American Tomato Pinworm Tuta absoluta. - PLoS ONE 7(10): e48068. doi:10.1371/journal.pone.0048068.

Collier T., VAn Steenwyk R.A., 2004 - Critical Evaluation of Augmentative Biological Control. Biological Control, 31(2): 245-256.

Cornelius M.L., Dieckhoff C., Hoelmer K.A., Olsen R.T., Weber D.C., Herlihy M.V., Talamas E.J., Vinyard B.T., Greenstone M.H., 2016 - Biological control of sentinel egg masses of the exotic invasive stink bug Halyomorpha halys (Stål) in Mid-Atlantic USA ornamental landscapes. - Biological Control, 103: 11-20.

Costi E., Maistrello L., Pansa M.G., Haye T., Tavella L., 2016 - A survey of native parasitoids of Halyomorpha halys in Northern Italy and Switzerland. - In: Proceedings of ICE 2016 - XXV International Congress of Entomology. Orlando, Florida (USA), doi: 10.1603/ ICE.2016.95318.

CROWDER D.W., 2007 - Impact of release rates on the effectiveness of augmentative biological control agents. Journal of Insect Science, 7(15): 1-11.

Cusumano A., Peri E., Vinson B., Colazza S., 2012 - The ovipositing female of Ooencyrtus telenomicida relies on physiological mechanisms to mediate intrinsic competition with Trissolcus basalis. - Entomologia Experimentalis et Applicata, 143: 155-163.

Cusumano A., Peri E., Vinson S.B., Colazza S., 2011 Intraguild interactions between two egg parasitoids exploring host patches. - BioControl, 56: 173-184.

Haye T., Gariepy T., Heolmer K., Rossi J.P., Streito J.C., Tassus X., DesneuX N., 2015a - Range expansion of the invasive brown marmorated stinkbug, Halyomorpha halys: an increasing threat to field, fruit and vegetable crops worldwide. - Journal of Pest Science, doi: 10.1007/s10340-015-0670-2.

Haye T., Fischer S., Zhang J., GariePy T., 2015b - Can native egg parasitoids adopt the invasive brown marmorated stink bug, Halyomorpha halys (Heteroptera: Pentatomidae), in Europe? - Journal of Pest Science, doi: 10.1007/s10340-015-0671-1.

Herlihy M.V., Talamas E.J., Weber D.C., 2016 - Attack and success of native and exotic parasitoids on eggs of Halyomorpha halys in three Maryland habitats. - PLoS ONE, 11(3): e0150275, doi:10.1371/journal.pone. 0150275 .

HoebeKe E.R., CARTER M.E., 2003 - Halyomorpha halys (Stål) (Heteroptera: Pentatomidae): a polyphagous plant 
pest from Asia newly detected in North America. Proceedings of the Entomological Society of Washington, 105: 225-237.

HuANG D.W., NoYes J.S., 1994 - A revision of Indo-Pacific species of Ooencyrtus. - Bulletin of the Natural History Museum, 63: 78-79.

JERVIS M.A., KIDD N.A.C., 1986 - Host-feeding strategies in hymenopteran parasitoids. - Biological Reviews, 61: 395-434.

Jones A.L., Jennings D.E., Hooks C.R.R., Shrewsbury P.M., 2014. - Sentinel eggs underestimate rates of parasitism of the exotic brown marmorated stink bug, Halyomorpha halys. - Biological Control, 78: 61-66.

Lara J., Pickett C., Ingels C., Haviland D.R., GraftonCardwell E., Doll D., BethKe J., Faber B., Dara S.K., HodDLE M., 2016 - Biological control program is being developed for brown marmorated stink bug. - California Agriculture, 70(1): 15-23.

Lee D., Short B.D., Joseph S.V., Bergh J.C., Leskey T.C., 2013 - Review of the Biology, Ecology, and Management of Halyomorpha halys (Hemiptera: Pentatomidae) in China, Japan, and the Republic of Korea. Environmental Entomology, 42(4): 627-641.

LeSKey T.C., LeE D.H., ShORT B.D., Wright S.E., 2012 Impact of insecticides on the invasive Halyomorpha halys (Hemiptera: Pentatomidae): analysis of insecticide lethality. - Journal Economic Entomology, 105: 17261735.

Maistrello L., Dioli P., Bariselli M., Mazzoli L., GiACALONE-Forini I., 2016 - Citizen science and early detection of invasive species: phenology of first occurrences of Halyomorpha halys in Southern Europe. Biological Invasions, doi: 10.1007/s10530-016-1217-z.

Maistrello L., Dioli P., Vaccari G., Nannini R., Bortolotti P., Caruso S., Costi E., Montermini A., CASOli L., BARISElli M., 2014 - Primi rinvenimenti in Italia della cimice esotica Halyomorpha halys, una nuova minaccia per la frutticoltura. - Atti Giornate Fitopatologiche, pp. 283-288.

MAPLE J.D., 1947 - The eggs and first instar larvae of Encyrtidae and their morphological adaptations for respiration. - University California Press, Berkeley, 122 pp.

MatošEvić D., MeliKa G., 2013 - Recruitment of native parasitoids to a new invasive host: first results of Dryocosmus kuriphilus parasitoid assemblage in Croatia. - Bulletin of Insectology, 66(2): 231-238.

Messing R.H., Wright M.G., 2006 - Biological control of invasive species: solution or pollution? Frontiers in Ecology and the Environment, 4(3): 132-140.

Ogburn E.C., Bessin R., Dieckhoff C, Dobson R. Grieshop M. Hoelmer K.A., Mathews C., Moore J., Nielsen A.L., Poley K., Pote J.M., Rogers M., Welty C., WalgenBaCh J.F., 2016 - Natural enemy impact on eggs of the invasive brown marmorated stink bug, Halyomorpha halys (Stål) (Hemiptera: Pentatomidae), in organic agroecosystems: A regional assessment. Biological Control, 101: 39-51.

Quacchia A., Ferracini C., Nicholls J.A., Piazza E., Saladini M., Tota F., Melika G., Alma A., 2013 Chalcid parasitoid community associated with the invading pest Dryocosmus kuriphilus in north-western Italy. - Insect Conservation and Diversity, 6: 114-123.

Rice K., Bergh C., Bergman E., Biddinger D., Dieckhoff C., Dively G., Fraser H., Gariepy T., Hamilton G., Haye T., Herbert A., Hoelmer K., Hooks C., Jones A., Krawczyk G., Kuhar T., Mitchell W., Nielsen A.,
Pfeiffer D., Raupp M., Rodriguez-SaOna C., Shearer P., Shrewsbury P., Venugopal P.D., Whalen J., Wiman N., Leskey T., ToOKer J., 2014 - Biology, ecology, and management of brown marmorated stink bug (Halyomorpha halys). - Journal of Integrated Pest Management, doi:10.1603/IPM14002.

Sabbatini Peverieri G., Furlan P., Benassai D., Strong W.B., ROVERSI P.F., 2015 - Long-term storage of eggs of Leptoglossus occidentalis for the mass-rearing of its parasitoid Gryon pennsylvanicum. - BioControl, doi: 10.1007/s10526-014-9644-1.

Samra S., Ghanim M., Protasov A., Mendel Z., 2015 Spatial distribution and niche partitioning in the Ooencyrtus spp. complex parasitizing the eggs of Stenozygum coloratum. BioControl, doi: 10.1007/s 10526-015-9683-2.

SFR REgione FVG, 2015 - Halyomorpha halys in Friuli Venezia Giulia. http://www.ersa.fvg.it/fitosanitaria/ cimice-marmorata-asiatica-halyomorpha halys/ $\mathrm{HH} \%$ 20in\%20FVG_14092015.pdf . Last access $3^{\text {th }}$ October 2016.

SFR Regione Toscana, 2016 - Halyomorpha halys, la cimice asiatica http://www.regione.toscana.it/ documents/10180/11270546/Nota-tecnica Halyomorphahalys.pdf/d7d798b3-558b-431a-8241-0f7c5b1d7d6e . Last access $3^{\text {th }}$ October 2016.

SimBerloff D., Stiling P., 1996 - How risky is Biological Control? - Ecology, 77: 1965-1974.

Sivinski J., 2013 - Augmentative biological control: research and methods to help make it work. $\mathrm{CAB}$ Reviews, 8 (026), doi: 10.1079/PAVSNNR20138026.

Stefanescu C., Pintureau B., Tschorsnig H., PujadeVILLAR J., 2003 - The parasitoid complex of the butterfly Iphiclides podalirius feisthamelii (Lepidoptera: Papilionidae) in north-east Spain. - Journal of Natural History, 37: 379-396.

Talamas E.J., Herlihy M.V., Dieckhoff C., Hoelmer K., Buffington M., Bon M.C., Weber D.C., 2015 Trissolcus japonicus (Ashmead) (Hymenoptera, Scelionidae) emerges in North America. - Journal of Hymenoptera Research, 43:119-128.

TRJAPITZIN V.A., 1988 - Family Eupelmidae. In: Keys to the Insects of the European Part of the USSR, Medvedev G.S. (ed.), Acad. Sci. USSR, 120, pp. 411-427.

VAN LENTEREN J.C., 2012 - The state of commercial augmentative biological control: plenty of natural enemies, but a frustrating lack of uptake. - BioControl, 57: $1-20$.

Van Lenteren J.C., Babendreier D., Bigler F., Burgio G., Hokkanen H.M.T., Kuske S., Loomans A.J.M., MENZler-Hokkanen I., VAN RiJn P.C.J., Thomas M.B., TOMMASINI M.G., ZENG Q.-Q., 2003 - Environmental risk assessment of exotic natural enemies used in inundative biological control. - BioControl, 48: 3-38.

VIGGIANI G., 1994 - Lotta biologica e integrata nella difesa fitosanitaria. - Liguori Editore, Napoli (Italy).

VINSON S.B., 1990 - How parasitoids deal with the immune system of their host: an overview. - Archives of Insect Biochemistry and Physiology, 13: 3-27.

Wermelinger B., Wyniger D., Forster B., 2008 - First records of an invasive bug in Europe: Halyomorpha halys Stål (Heteroptera: Pentatomidae), a new pest on woody ornamentals and fruit trees? - Mitteilungen der Schweizerischen Entomologischen Gesellschaft, 81(1-2): 1-8.

ZAR J.H., 2010 - Biostatistical analysis. Prentice Hall, Englewood Cliffs, NJ., 5th ed. 